\title{
Surgery for Complicated Stomal Prolapse: Is the Altemeier Technique an Option? A Report of Three Cases
}

\section{Cirurgia para prolapso de estoma complicado: A técnica de Altemeier é uma opção? Um relato de três casos}

\author{
Tamer R. Alalfy ${ }^{1}$ Yasser A. Orban ${ }^{1}$ Mohammed Algazar $^{10}$ Ahmed Farag ${ }^{1(0)}$ \\ ${ }^{1}$ Department of General Surgery, Faculty of Medicine, Zagazig \\ University, Zagazig, Egypt \\ Address for correspondence Mohammed Algazar, MD, Department \\ of General Surgery, Faculty of Medicine, Zagazig University, Zagazig, \\ Egypt (e-mail: drmohammedezzat4@gmail.com).
}

J Coloproctol 2021;41(1):37-41.

\begin{abstract}
Keywords

- Altemeier technique

- stoma

- abdominoperineal resection

- end colostomy

- irreducible prolapse

Resumo
\end{abstract}

Introduction The incidence of stomal prolapse ranges from $2 \%$ to $22 \%$. The risk factors include colostomy, the short length of the stoma, obesity, emergency surgery, and the improper (or even absence of) marking of the preoperative site for the stoma. Complicated stomal prolapse associated with severe mucosal irritation, ischemic changes, or bleeding requires surgical intervention.

Objective To describe the use of the Altemeier technique in the management of cases of complicated prolapsed stoma after failure of the local medical measures and manual reduction.

Methods Case series of three patients with past history of abdominoperineal resection of rectal cancer and permanent end colostomy presented with irreducible prolapse of the stoma. After the failure of the local measures and manual reduction, urgent surgical intervention using the modified Altemeier technique was necessary.

Results The modified Altemeier technique is simple, presents low risk of operative and postoperative complications, besides enabling an early recovery, with a lower risk of recurrence during the first 6 months after the repair.

Conclusion The modified Altemeier technique may be a valid therapeutic modality in the setting of complicated prolapsed stoma.

Introdução A incidência de prolapso de estoma varia de 2 a $22 \%$. Os fatores de risco incluem colostomia, comprimento curto do estoma, obesidade, cirurgias de emergência, e marcação não adequada (ou até mesmo ausente) do sítio pré-operatório para o estoma. Prolapso de estoma complicado e associado a irritação grave de mucosa, alterações isquêmicas, ou sangramento requer intervenção cirúrgica.

Objetivo Descrever o uso da técnica de Altemeier para o manejo de prolapso de estoma complicado após fracasso das medidas médicas locais e da redução manual. received

July 3, 2020

accepted

August 18, 2020
DOI https://doi.org/

$10.1055 / \mathrm{s}-0041-1724060$. ISSN 2237-9363.
(C) 2021. Sociedade Brasileira de Coloproctologia. All rights reserved.

This is an open access article published by Thieme under the terms of the Creative Commons Attribution-NonDerivative-NonCommercial-License, permitting copying and reproduction so long as the original work is given appropriate credit. Contents may not be used for commercial purposes, or adapted, remixed, transformed or built upon. (https://creativecommons.org/ licenses/by-nc-nd/4.0/)

Thieme Revinter Publicações Ltda., Rua do Matoso 170, Rio de Janeiro, RJ, CEP 20270-135, Brazil 


\section{Palavras-chave}

- técnica de Altemeier

- estoma

- ressecção abdominoperineal

- colostomia terminal

- prolapso irredutível
Métodos Série de casos de três pacientes com histórico de ressecção abdominoperineal de câncer retal e colostomia terminal permanente apresentaram prolapso irredutível do estoma. Com o fracasso das medidas locais e da redução manual, fezse necessária intervenção cirúrgica de emergência usando a técnica de Altemeier modificada.

Resultados A técnica de Altemeier modificada é simples e apresenta risco baixo de complicações operatórias e pós-operatórias, além de possibilitar uma recuperação precoce, com menor risco de recorrência durante os 6 primeiros meses após o reparo. Conclusão A técnica de Altemeier modificada pode ser uma modalidade terapêutica válida em casos de prolapso de estoma complicado.

\section{Introduction}

As a part of the surgical treatment of abdominal diseases, surgeons may temporarily or permanently divert the passage of stool through the creation of an abdominal stoma. Whether end or loop stomas, ileostomies and colostomies are still the most commonly performed abdominal stomas. ${ }^{1-3}$ Stomarelated morbidity ranges from $20 \%$ to $70 \%{ }^{1,3-7}$ It has been proposed that the increase in the incidence of stoma-related complications may be due to colostomy, short length of the stoma, obesity, emergency surgery, and the improper (or even absence of) marking of the preoperative site for the stoma. ${ }^{7}$ Stomal prolapse is a late complication, and its incidence ranges from $2 \%$ to $22 \%$. Many studies ${ }^{1,8-10}$ have reported an increased incidence of stomal prolapse with loop stomas being rare with loop ileostomies and up to $19 \%$ with loop colostomies. However, Law et al. ${ }^{11}$ reported a low association of loop-colostomy prolapse and a small fascial defect, but they did not recommend the exact proper size of the fascial defect.

To prevent stomal prolapse, some surgeons have advocated fixation of the mesentery or the bowel at the fascial level, or extraperitoneal tunneling, but have others claimed this is useless. ${ }^{10,12,13}$

Simple non-complicated stomal prolapse could be conservatively managed with manual reduction following application of cold compresses or osmotic agents. ${ }^{14,15}$ However, limited surgical options are available for the treatment of complicated or long-standing stomal prolapse, and they include takedown of the temporary stoma, resection, revision or relocation. ${ }^{5}$

In the present study, we modified the Altemeier technique, which is used to treat the rectal prolapse, for the treatment of irreducible prolapsed end colostomies after abdominoperineal resection of cases of low anal cancer. ${ }^{16}$

\section{Methods}

Our report for the modified Altemeier technique includes three patients. No staples were used in the treatment of the stomal prolapse.

Abdominoperineal resection with permanent colostomy was performed in all of the patients, who presented with irreducible stomal prolapses that did not respond to the local medical management and manual reduction. With increased edema and impending signs of strangulation in the prolapsed stoma, the modified Altemeier technique was used to resect the prolapsed stomas.

The prolapsed stomas were end colostomies (descending colon). We evaluated the preoperative risk of the patients according to the American Society of Anesthesiologists, ${ }^{17}$ the duration of the surgery and intraoperative bleeding, the length of the hospital stay, and the follow-up at six months for the recurrence of prolapse, hernia or intestinal obstruction.

The surgery was performed under general anesthesia. After prepping and dragging the patients, we started a round incision at $\sim 1.5 \mathrm{~cm}$ to $2 \mathrm{~cm}$ distal to the mucocutaneous junction, through the outer cylinder of the prolapsed

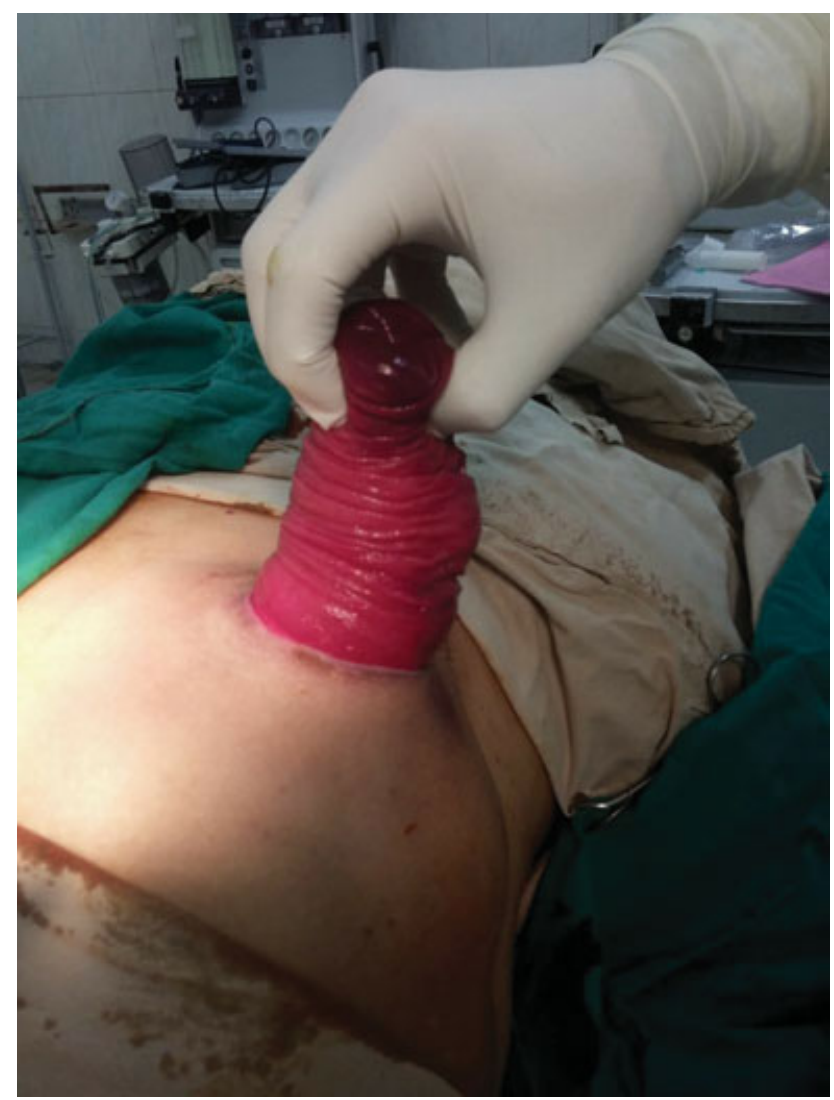

Fig. 1 Assessment of the prolapsed end colostomy (descending colon). 


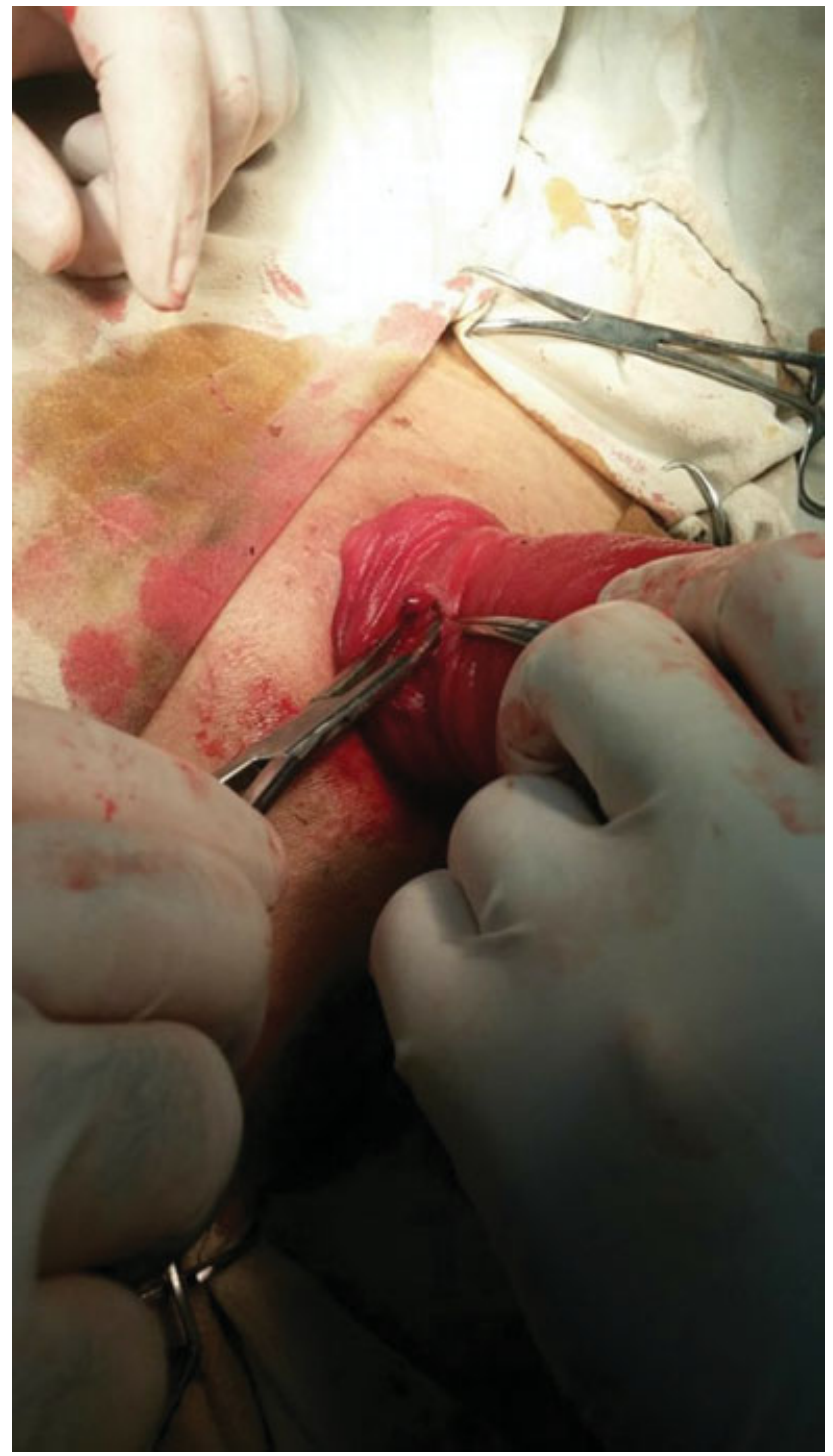

Fig. 2 Line of dissection to separate the outer and inner tubes.

colostomy, and then, through the inner cylinder, including ligation and division of the mesentery and tracking it until no mesentery was oberved at the colostomy site. After complete hemostasis of the cut edges of both the outer and inner cylinders, we made a one-layer colocolostomy anastomosis using absorbable polyglactin 910 3/0 suture. Normal-sized colostomy bags were installed and well-fitted, and the steps are shown in -Figs. 1-4.

\section{Results}

The clinical characteristics of the included patients are presented in - Table 1.

No major intra- or postoperative complications were observed in these patients. None of the patients experienced recurrence of the prolapse, hernias, obstruction, or even recurrence of the primary disease for a period of 6 months after being submitted the modified Altemeier technique. The operative and postoperative variables are shown in -Table 2.

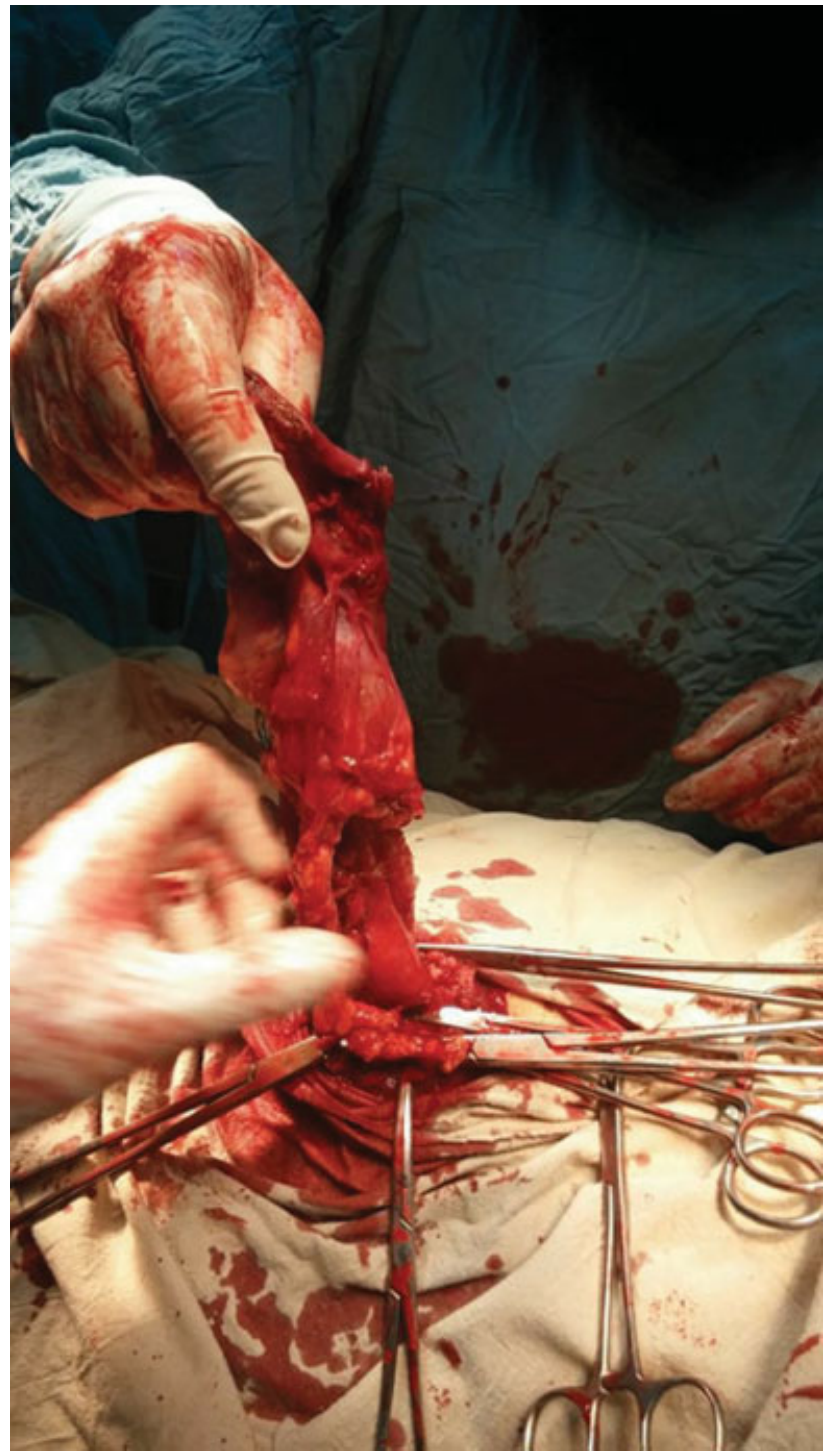

Fig. 3 Complete separation of half the circumference of each cylinder and resection of the mesentery.

\section{Discussion}

The Altemeier technique is the most frequently performed technique in the United States for the treatment of rectal procidentia with a length $\leq 4 \mathrm{~cm} .{ }^{16,18}$ In the present study, the patients complained of progressive symptoms of intermittent intestinal obstruction and then presented with irreducible stomal prolapse. In a review of the literature, we found the use of the Delorme technique for treatment of the prolapse of an end loop colostomy in a patient after treatment for stage-IV rectal cancer. ${ }^{19}$ Watanabe et al. ${ }^{20}$ described the use of the modified Altemeier technique as a surgical treatment for the prolapse of transverse loop colostomies in a case series of three patients with primary diseases: perforated rectosigmoid diverticulitis, perforated diverticulitis, and unresectable sigmoid cancer. In our case series, we described the successful use of the modified Altemeier technique in the urgent management of complicated prolapsed end colostomies in the three patients. To the best of our knowledge, this is the 


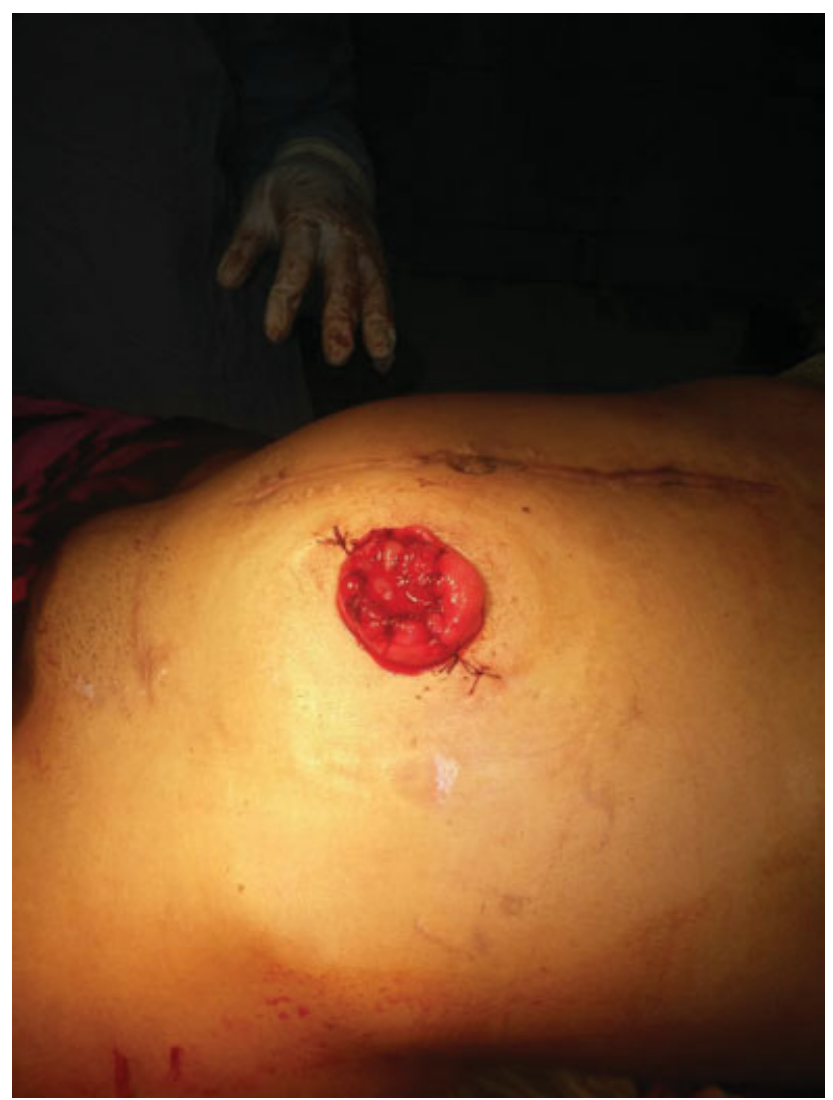

first experience of management of complicated prolapsed stoma using this technique. Moreover, the technique is simple, presents a low risk of operative and postoperative complications, and enables an early recovery, with a lower risk of recurrence during the first 6 months after the repair. We used the hand-sewn Altemeier technique, which saved the costs of using staples.

We think the use of the modified Altemeier technique for the surgical correction of end colostomies in this specific group of patients may be a valid option due to its simplicity, the shorter duration of the surgery and of the hospital stay, and because, on the short-term, no complications were detected. The patients will remian under follow-up for a longer period in order for us to assess the long-term complications of this technique.

Fig. 4 Anastomosis of the one-layer colocolostomy.

Table 1 Clinical characteristics of the patients

\begin{tabular}{|l|l|l|l|}
\hline & Patient 1 & Patient 2 & Patient 3 \\
\hline Age (years) & 40 & 52 & 60 \\
\hline Gender & Female & Male & Male \\
\hline Primary disease & $\begin{array}{l}\text { Cancer of the } \\
\text { lower rectum }\end{array}$ & Anorectal cancer & Anorectal cancer \\
\hline Staging of the primary disease & T3N2M0 & Not known & T3N0M0 \\
\hline Primary procedure & $\begin{array}{l}\text { Abdominoperineal } \\
\text { resection }\end{array}$ & $\begin{array}{l}\text { Abdominoperineal } \\
\text { resection }\end{array}$ & $\begin{array}{l}\text { Abdominoperineal } \\
\text { resection }\end{array}$ \\
\hline $\begin{array}{l}\text { American Society of Anesthesiologists } \\
\text { (ASA) physical status classification system }\end{array}$ & ASA I & ASA I & ASA II \\
\hline Type of stoma & End-colostomy & End-colostomy & End-colostomy \\
\hline $\begin{array}{l}\text { Time of the prolapse after the } \\
\text { primary surgery (months) }\end{array}$ & 7 & 5 & 6 \\
\hline
\end{tabular}

Table 2 Operative and postoperative outcomes

\begin{tabular}{|l|l|l|l|}
\hline & Patient 1 & Patient 2 & Patient 3 \\
\hline Duration of the procedure (min) & 60 & 65 & 55 \\
\hline Intraoperative blood loss (ml) & 50 & 30 & 30 \\
\hline Sutures used & Polyglactin 910 3/0 & 2 \\
\hline Length of hospital stay (days) & 3 & 2 & \\
\hline Postoperative complications & None & \multicolumn{2}{|l|}{} \\
\hline Follow-up (months) & 6 & \multicolumn{2}{|l|}{} \\
\hline
\end{tabular}




\section{Conflict of Interests}

The authors have no conflict of interests to declare.

\section{Acknowledgments}

We would like to thank the faculty and staff of the Department of Surgery and the Emergency Medical Unit, Faculty of Medicine, Zagazig University, Egypt.

\section{References}

1 Harris DA, Egbeare D, Jones S, Benjamin H, Woodward A, Foster ME. Complications and mortality following stoma formation. Ann R Coll Surg Engl 2005;87(06):427-431

2 Shellito PC. Complications of abdominal stoma surgery. Dis Colon Rectum 1998;41(12):1562-1572

3 Shabbir J, Britton DC. Stoma complications: a literature overview. Colorectal Dis 2010;12(10):958-964

4 Formijne Jonkers HA, Draaisma WA, Roskott AM, van Overbeeke AJ, Broeders IA, Consten EC. Early complications after stoma formation: a prospective cohort study in 100 patients with 1-year follow-up. Int J Colorectal Dis 2012;27(08):1095-1099

5 Bafford AC, Irani JL. Management and complications of stomas. Surg Clin North Am 2013;93(01):145-166

6 Cottam J, Richards K, Hasted A, Blackman A. Results of a nationwide prospective audit of stoma complications within 3 weeks of surgery. Colorectal Dis 2007;9(09):834-838

7 Parmar KL, Zammit M, Smith A, Kenyon D, Lees NPGreater Manchester and Cheshire Colorectal Cancer Network. A prospective audit of early stoma complications in colorectal cancer treatment throughout the Greater Manchester and Cheshire colorectal cancer network. Colorectal Dis 2011;13(08):935-938

8 Park JJ, Del Pino A, Orsay CP, et al. Stoma complications: the Cook County Hospital experience. Dis Colon Rectum 1999;42(12): 1575-1580

9 Arumugam PJ, Bevan L, Macdonald L, et al. A prospective audit of stomas-analysis of risk factors and complications and their management. Colorectal Dis 2003;5(01):49-52
10 Maeda K, Maruta M, Utsumi T, Sato H, Masumori K, Aoyama H. Pathophysiology and prevention of loop stomal prolapse in the transverse colon. Tech Coloproctol 2003;7(02):108-111

11 Law WL, Chu KW, Choi HK. Randomized clinical trial comparing loop ileostomy and loop transverse colostomy for faecal diversion following total mesorectal excision. Br J Surg 2002;89(06): 704-708

12 Mäkelä JT, Turku PH, Laitinen ST. Analysis of late stomal complications following ostomy surgery. Ann Chir Gynaecol 1997;86 (04):305-310

13 Londono-Schimmer EE, Leong AP, Phillips RK. Life table analysis of stomal complications following colostomy. Dis Colon Rectum 1994;37(09):916-920

14 Colwell JC, Goldberg M, Carmel J. The state of the standard diversion. J Wound Ostomy Continence Nurs 2001;28(01):6-17

15 Shapiro R, Chin EH, Steinhagen RM. Reduction of an incarcerated, prolapsed ileostomy with the assistance of sugar as a desiccant. Tech Coloproctol 2010;14(03):269-271

16 Altemeier WA, Culbertson WR, Schowengerdt C, Hunt J. Nineteen years' experience with the one-stage perineal repair of rectal prolapse. Ann Surg 1971;173(06):993-1006

17 Apfelbaum JL, Connis RT, Nickinovich DG, et al; Committee on Standards and Practice Parameters American Society of Anesthesiologists Task Force on Preanesthesia Evaluation. Practice advisory for preanesthesia evaluation: an updated report by the American Society of Anesthesiologists Task Force on Preanesthesia Evaluation. Anesthesiology 2012;116(03): 522-538

18 Lindsey I. Commentary: Best practice in rectal prolapse. Colorectal Dis 2010;12(06):512-514

19 Marrosu A, Paliogiannis P, Sassu MA, Attene F, Trignano M. Correction of an end colostomy prolapse with the Delorme technique. A case report. Ann Ital Chir 2012;83(06): 567-569

20 Watanabe M, Murakami M, Ozawa Y, et al. The modified Altemeier procedure for a loop colostomy prolapse. Surg Today 2015; 45(11):1463-1466 